\title{
ALLELE FREQUENCIES OF INTRAGENIC, AND 5' AND 3' MARKERS OF THE DYSTROPHIN GENE IN JAPANESE FAMILIES AFFLICTED WITH DUCHENNE OR BECKER MUSCULAR DYSTROPHY
}

\author{
Hiroko Tsukamoto, Koji Inui, * Hisao Fukushima, \\ and Shintaro OKADA \\ Department of Pediatrics, Faculty of Medicine, Osaka University, \\ 2-2 Yamadaoka, Suita, Osaka 565, Japan
}

\begin{abstract}
Summary Using the polymerase chain reaction method (PCR), we examined the allele frequencies and heterozygosities of 7 polymorphic sites (pERT87, and CA polymorphisms in the $5^{\prime}$ and $3^{\prime}$ regions) of the dystrophin gene in 20 Japanese Duchenne muscular dystrophy and Becker muscular dystrophy (DMD or BMD) families consisting of 36 males, including 23 cases of DMD and BMD, and 28 females. The allele frequencies of three primer and enzyme sets in the pERT87 locus were well comparable to those in the previously reported Japanese female cases but different from in other countries. The frequencies of $5^{\prime}$ markers of the dystrophin gene in Japanese were different from the reported Caucasian frequencies. As for 5'DYS-I and 5'DYS-II, the numbers of alleles in our cases were less than in Caucasians, and the heterozygosities of all three markers (5'DYS-I, II and III) were lower than in Caucasians. However, the 3'CA polymorphisms showed almost the same frequencies and heterozygosities as in Caucasians. All of our females showed a heterozygous pattern for at least one locus, with the combination of the seven markers. The usefulness of linkage analysis involving PCR methods with these intragenic, and $5^{\prime}$ and $3^{\prime}$ markers of the dystrophin gene in the carrier and prenatal diagnosis of DMD and BMD was confirmed by the successful prenatal diagnoses in 15 fetuses, the exception being one case considered to have a new mutation.
\end{abstract}

Key Words dystrophin gene, polymerase chain reaction, pERT87, CA repeat, allele frequency

Received May 8, 1996; Revised version accepted July 29, 1996.

* To whom correspondence should be addressed. 


\section{INTRODUCTION}

The Duchenne and Becker muscular dystrophies (DMD and BMD) are allelic, $\mathrm{X}$-linked disorders resulting in progressive muscular degeneration. DMD occurs with an incidence of one in 3,500 male births, making it the most common lethal $\mathrm{X}$-linked disorder in man (Emery, 1988). After isolation of the complete cDNA of dystrophin, about $60 \%$ of DMD mutations have been detected by Southern blot analysis (Koenig et al., 1989; Lindlof et al., 1989), and the polymerase chain reaction method (PCR) (Chamberlain et al., 1990; Beggs et al., 1990). The remaining $40 \%$ of DMD cases do not show any deletions. In such DMD families, linkage analysis involving DNA markers of flanking and intragenic dystrophin gene is necessary for carrier and prenatal diagnosis (Darras et al., 1987; Lindlof et al., 1986; Beggs and Kunkel, 1990). Several reports of carrier and prenatal diagnoses using polymorphic markers have been appeared (Roberts et al., 1989; Feener et al., 1991; Oudet et al., 1990; Clemens et al., 1991; Gokgoz et al., 1993; Kruyer et al., 1994). In this paper, we report the allele frequencies of 7 polymorphic sites (pERT87 and CA polymorphisms in the $5^{\prime}$ and $3^{\prime}$ regions) in Japanese DMD or BMD families, and the usefulness for carrier and prenatal diagnoses in 20 DMD or BMD families.

\section{MATERIALS AND METHODS}

Total DNA was extracted by the phenol-chloroform method from peripheral blood samples from 36 males and 28 females from 20 families, including 23 cases of DMD or BMD. In 4 families, DNA was extracted from cultured amniotic fluid cells of fetuses at risk for DMD or BMD. The diagnosis of DMD or BMD was made in all cases on the basis of the clinical manifestations, family history, serum creatine kinase values, and DNA analysis and muscle biopsy findings, including immunohistochemical dystrophin staining in some cases. The materials, including restriction enzymes, $T a q$ polymerase and biochemical materials, were purchased from commercial suppliers.

Linkage analysis using the pERT87 locus. Three sets of oligonucleotide primers within the dystrophin gene (pERT87-15/BamHI, pERT87-8/TaqI, and pERT87-15/XmnI) were prepared (Roberts et al., 1989). Amplification was performed through 30 cycles of denaturation $\left(94^{\circ} \mathrm{C}, 30 \mathrm{sec}\right)$, annealing $\left(55^{\circ} \mathrm{C}, 30\right.$ $\mathrm{sec}$ ) and extension $\left(72^{\circ} \mathrm{C}, 3 \mathrm{~min}\right)$, using an automated thermocycler (Astec Co., Japan). After extraction with phenol and chloroform, and precipitation with ethanol and $3 \mathrm{~m}$ sodium acetate, the PCR products were digested with the respective restriction enzymes for $3 \mathrm{hr}$ according to the manufacturers' protocols, and the digested samples were analyzed by electrophoresis on $2.5 \%$ agarose gels containing ethidium bromide.

Linkage analysis using $C A$ repeat polymorphism. Eight reported oligonu- 
cleotide primers (5'DYS-I, 5'DYS-II, 5'DYS-III, 3'CA) (Feener et al., 1991; Oudet et al., 1990) were synthesized. Each antisense primer was labelled at its $5^{\prime}$ end with ${ }^{32} \mathrm{P}-\mathrm{dATP}(6,000 \mathrm{Ci} / \mathrm{nmol}$, NEN, Japan) using T4 polynucleotide kinase according to the instructions (TOYOBO, Japan). PCR was carried out in a volume of 5 $\mu 1$ comprising $20 \mathrm{ng}$ DNA, 2 pmol unlabelled primer, $0.2 \mathrm{pmol}$ end-labelled primer, $200 \mu \mathrm{M}$ each dNTP, $50 \mathrm{mM} \mathrm{KCl}, 10 \mathrm{~mm}$ Tris- $\mathrm{HCl}$ ( $\mathrm{pH} 8.0$ ), $1.5 \mathrm{mM} \mathrm{MgCl}_{2}$, and $0.1 \mathrm{U}$ Taq polymerase (Promega, USA). Two different sets of amplification conditions were used. For the primer sets of 5'DYS-I and $3^{\prime} \mathrm{CA}$, denaturation was carried out at $94^{\circ} \mathrm{C}$ for $30 \mathrm{sec}$, and annealing and extension at $65^{\circ} \mathrm{C}$ for $4 \mathrm{~min}$ (Beggs et al., 1990; Feener et al., 1991). The amplification conditions for primer sets $5^{\prime} \mathrm{DYS}-\mathrm{II}$ and $5^{\prime} \mathrm{DYS}$-III were denaturation at $94^{\circ} \mathrm{C}$ for $30 \mathrm{sec}$, annealing at $55^{\circ} \mathrm{C}$ for $30 \mathrm{sec}$, and extension at $63^{\circ} \mathrm{C}$ for $4 \mathrm{~min}$ (Chamberlain et al., 1988; Feener et al., 1991). The reaction products were each mixed with $3 \mu 1$ sequence loading buffer and boiled for $3 \mathrm{~min}$. A $1.5 \mu 1$ of each mixtures was loaded onto each lane of $8 \%$ polyacrylamide and $40 \%$ urea sequencing gels with a known sequence DNA as a size marker. Electrophoresis was performed at $35 \mathrm{~W}$ constant power for $2.5 \mathrm{hr}$. The gels were fixed in 10\% acetic acid and 10\% methanol, dried, and then autoradiographed on films at $-80^{\circ} \mathrm{C}$ for $1-24 \mathrm{hr}$.

\section{RESULTS}

pERT87 analysis

The allele frequencies in the 64 members (28 females) in 20 DMD families are shown in Table 1 . The heterozygosities in the females were $46 \%, 36 \%$ and $50 \%$ for pERT87-15/BamHI, pERT87-8/TaqI and pERT87-15/XmnI, respectively, with polymorphism information content (PIC) values in the range of $0.455-0.500$. Sixty-eight percent of the females showed a heterozygous pattern for at least one

Table 1. Allele and heterozygote frequencies of the pERT87 locus.

\begin{tabular}{|c|c|c|c|c|c|c|}
\hline \multirow[b]{2}{*}{ Allele } & \multicolumn{4}{|c|}{ Our cases } & \multicolumn{2}{|c|}{ Reported cases } \\
\hline & \multicolumn{2}{|c|}{ Frequency } & \multirow[t]{2}{*}{$\begin{array}{l}\text { Heterozygous } \\
(\%)\end{array}$} & \multirow[t]{2}{*}{ PIC } & \multirow[t]{2}{*}{ Frequency } & \multirow[t]{2}{*}{ PIC } \\
\hline & $\begin{array}{c}\text { Total } \\
64\end{array}$ & $\begin{array}{c}\text { Female } \\
28\end{array}$ & & & & \\
\hline A: Allele $(+)$ & 0.652 & 0.625 & & & $0.62^{*}$ & \\
\hline$(-)$ & 0.348 & 0.375 & 46 & 0.455 & $0.38^{*}$ & 0.47 \\
\hline \multirow{2}{*}{ B: Allele $\begin{array}{r}(+) \\
(-)\end{array}$} & 0.348 & 0.357 & & & $0.74 * *$ & \\
\hline & 0.652 & 0.643 & 36 & 0.455 & $0.26 * *$ & 0.38 \\
\hline \multirow{2}{*}{$\begin{array}{r}\text { C: Allele }(+) \\
(-)\end{array}$} & 0.510 & 0.536 & & & $0.68 * * *$ & \\
\hline & 0.490 & 0.464 & 50 & 0.500 & $0,32 * * *$ & 0.44 \\
\hline \multicolumn{7}{|c|}{ 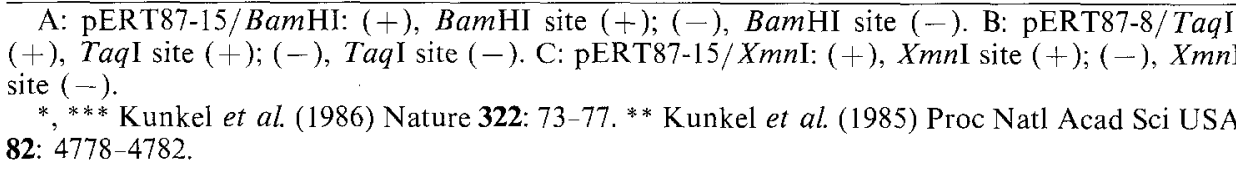 } \\
\hline
\end{tabular}


of the three combinations (Tables 1 and 4).

$C A$ repeat analysis

The frequencies of observed alleles and heterozygous percentages in the females for each 5' end marker (5'DYS-I, 5'DYS-II and 5'DYS-III) and the $3^{\prime}$ end marker $\left(3^{\prime} \mathrm{CA}\right)$ are summarized in Tables 2 and 3 . In our Japanese cases, only two

Table 2. Allele and heterozygote frequencies of $5^{\prime}$ dystrophin markers.

\begin{tabular}{|c|c|c|c|c|c|c|c|}
\hline \multirow{3}{*}{$\begin{array}{l}\text { Marker } \\
\text { and allele }\end{array}$} & \multicolumn{4}{|c|}{ Our cases } & \multicolumn{3}{|c|}{ Reported cases* } \\
\hline & \multicolumn{2}{|c|}{ Frequency } & $\begin{array}{c}\text { Heterozygous } \\
(\%)\end{array}$ & PIC & $\begin{array}{c}\text { Fre- } \\
\text { quency }\end{array}$ & $\begin{array}{c}\text { Heterozygous } \\
(\%)\end{array}$ & PIC \\
\hline & $\begin{array}{c}\text { Total } \\
63\end{array}$ & $\begin{array}{c}\text { Female } \\
27\end{array}$ & & & & $\begin{array}{c}\text { Female } \\
42\end{array}$ & \\
\hline 5'DYS-I & & & 44.4 & 0.384 & & 78.6 & 0.608 \\
\hline Al (185 bp) & 0 & 0 & & & 0.048 & & \\
\hline A2 (183 bp) & 0 & 0 & & & 0.071 & & \\
\hline A3 (181 bp) & 0.311 & 0.259 & & & 0.310 & & \\
\hline A4 (179 bp) & 0.689 & 0.741 & & & 0.536 & & \\
\hline A5 (177bp) & 0 & 0 & & & 0.036 & & \\
\hline 5’DYS-II & & & 51.9 & 0.626 & & 82.0 & 0.768 \\
\hline Al (228 bp) & 0.167 & 0.130 & & & 0.090 & & \\
\hline A2 (226 bp) & 0.144 & 0.148 & & & 0.077 & & \\
\hline A3 (224bp) & 0 & 0 & & & 0.103 & & \\
\hline A4 (222 bp) & 0.056 & 0.074 & & & 0.026 & & \\
\hline A5 (220bp) & 0 & 0 & & & 0.103 & & \\
\hline A6 (218bp) & 0.022 & 0 & & & 0.192 & & \\
\hline A7 (216 bp) & 0.078 & 0.074 & & & 0.013 & & \\
\hline A8 (214 bp) & 0.533 & 0.574 & & & 0.397 & & \\
\hline 5'DYS-III & & & 70.4 & 0.707 & & 51.0 & 0.586 \\
\hline $\mathrm{Al}(225 \mathrm{bp})$ & 0.122 & 0.130 & & & 0.057 & & \\
\hline A2 (223bp) & 0.356 & 0.333 & & & 0.529 & & \\
\hline A3 (221 bp) & 0.133 & 0.167 & & & 0.057 & & \\
\hline A4 (219 bp) & 0.389 & 0.370 & & & 0.357 & & \\
\hline
\end{tabular}

* Feener et al. (1991) Am J Hum Genet 48: 621-627.

Table 3. Allele and heterozygote frequencies of $3^{\prime}$ dystrophin markers.

\begin{tabular}{|c|c|c|c|c|c|c|c|}
\hline \multirow{2}{*}{$\begin{array}{l}\text { Marker } \\
\text { and allele }\end{array}$} & \multicolumn{4}{|c|}{ Our cases } & \multicolumn{3}{|c|}{ Reported cases* } \\
\hline & \multicolumn{2}{|c|}{ Allele frequency } & \multirow[t]{3}{*}{$\begin{array}{c}\text { Heterozygous } \\
(\%)\end{array}$} & \multirow[t]{3}{*}{ PIC } & \multirow{3}{*}{$\begin{array}{l}\text { Alle fre- } \\
\text { quency }\end{array}$} & \multirow{3}{*}{$\begin{array}{c}\begin{array}{c}\text { Heterozygous } \\
(\%)\end{array} \\
\text { Female } \\
27\end{array}$} & \multirow[t]{3}{*}{$\mathrm{PIC}$} \\
\hline & Total & Female & & & & & \\
\hline & 63 & 27 & & & & & \\
\hline $3^{\prime} \mathrm{CA}$ & & & 40.7 & 0.337 & & 37.0 & 0.34 \\
\hline A1 (137bp) & 0.144 & 0.167 & & & 0.22 & & \\
\hline$A 2(133 b p)$ & 0.822 & 0.796 & & & 0.76 & & \\
\hline$A 3(121 b p)$ & 0.033 & 0.037 & & & 0.02 & & \\
\hline A4 (119 bp) & 0 & 0 & & & & & \\
\hline
\end{tabular}


Table 4. Heterozygosity of the pERT87 locus and the CA repeat.

\begin{tabular}{lc}
\hline Marker & \% Heterozygous \\
\hline 1) pERT87 locus & Female 28 \\
A: $87-15 /$ Bam HI & 46 \\
B: $87-8 /$ Taq & 36 \\
C: $87-15 /$ XmnI & 50 \\
A, B, C & 68 \\
2) CA repeat & Female 27 \\
5'DYS-I & 44 \\
5'DYS-II & 52 \\
5'DYS-II & 70 \\
3'CA & 41 \\
5'DYS-I, II, III & 85 \\
5'DYS-I, II, III, 3'CA & 93 \\
3) pERT87 (A, B, C) & 100 \\
+5'DYS-I, II, III, 3'CA & \\
\hline
\end{tabular}

alleles for 5'DYS-I and six alleles for 5'DYS-II were detected, compared to five and eight alleles detected in Caucasians (Feener et al., 1991), which resulted in low heterozygosities for these alleles. However, the heterozygosity percentages for 5'DYS-III and 3'CA were higher than the values reported for Caucasians (Feener et al., 1991; Oudet et al., 1990). Eighty-five percent of the females showed a heterozygous pattern for at least one of the three $5^{\prime}$ end loci (5'DYS-I, 5'DYS-II and 5'DYS-III), and 93\% heterozygosity was detected on inclusion of the $3^{\prime} \mathrm{CA}$ repeat (Table 4). However, only $22 \%$ of the females showed a heterozygous pattern for both the $5^{\prime}$ and $3^{\prime} \mathrm{CA}$ haplotype repeats.

All the females showed a heterozygous pattern for at least one of seven markers, three pERT87 and four CA markers (Table 4).

By PCR analysis with the seven markers, we could make successful carrier and prenatal diagnoses. On the examination of 15 fetuses at risk for DMD or BMD, only one undiagnosed male fetus was found. In this case, the haplotype of the elder brother with DMD was the same as in the healthy younger brother and in the male fetus at risk.

\section{DISCUSSION}

The allele frequencies in the pERT87 locus detected with three combinations of primer and enzyme sets were well comparable to those previously reported for Japanese and Chinese females (Akita et al., 1987; Shimmoto et al., 1988; Sugino et al., 1989; Fujishita et al., 1991; Soong et al., 1991). However, they were quite different from those in the Caucasian, Spanish, Indian and black populations (Kunkel et al., 1985, 1986; Lindlof et al., 1987; Schwartz and Barjon, 1987; Roberts et al., 1989; Gokgoz et al., 1993; Al-Maghtheh et al., 1993). The most characteristic difference was in the pERT87-8/TaqI site, which was positively 
detected in only $35 \%$ of our Japanese cases, but in $74 \%$ of Caucasians (Kunkel et al., 1986). The allele frequencies of 5'DYS-I, II and III were also different from those previously reported for Caucasians in the following point: only two patterns for 5'DYS-I and six patterns for 5'DYS-II were found in Japanese, five patterns and eight patterns having been found in Caucasians respectively, therefore the heterozygosity frequencies in Japanese females in the three loci were lower than those in Caucasians, the most frequent allele of 5'DYS-III being A4 (219 bp) in Japanese and A2 (223 bp) in Caucasians (Feener et al., 1991). However, the heterozygosity of $3^{\prime} \mathrm{CA}$ was slightly higher than in Caucasians. The rare allele, A3 (121 bp), was also detected in our Japanese cases (Oudet et al., 1990). These results indicated that the allele frequencies of polymorphic markers in the dystrophin gene differ among races. pERT87-15/XmnI, 5'DYS-III and $3^{\prime} \mathrm{CA}$ are more informative markers in Japanese because each marker shows high heterozygosity and a high PIC value (Tables 1, 2 and 3).

With the three primer sets of the pERT87 locus or the four primer sets of the CA repeat, $68 \%$ and $93 \%$ of the females examined in this study showed heterozygosity in at least one of the three and four loci, respectively. With all seven primer sets, all the females showed heterozygosity. We could also make successful prenatal diagnoses in 15 fetuses at risk for DMD or BMD, there being one exception, by deletion analysis involving PCR and PCR-RFLP analysis with the seven markers. Rapid and useful PCR-RFLP analysis with these combinations of polymorphic markers in the dystrophin gene is very important and necessary for correct carrier and prenatal diagnoses in DMD or BMD families. However, about $11 \%$ of intragenic recombination has to be taken into account when these polymorphic markers are used for diagnostic application (Oudet et al., 1991).

Acknowledgments This study was supported in part by Grants-in-Aid for Scientific Research from the Ministry of Education, Science, Sports and Culture of Japan, and by grants from the Ministry of Health and Welfare of Japan.

\section{REFERENCES}

Akita Y, Ohno S, Goto J, Nakano 1, Takatsu M, Sugita H, Suzuki K (1987): Diagnosis of Duchenne and Becker muscular dystrophies by DNA polymorphism. Jpn J Hum Genet 32: $71-82$

Al-Maghtheh M, Ray V, Mastana SS, Garralda MD, Bhattacharya SS, Papiha SS (1993): Variation in DNA polymorphisms of the short arm of the human $X$ chromosome: genetic affinity of Parsi from Western India. Hum Hered 43: 239-243

Beggs AH, Koenig M, Boyce FM, Kunkel LM (1990): Detection of 98\% of DMD/BMD gene deletions by polymerase chain reaction. Hum Genet 86: 45-48

Beggs AH, Kunkel LM (1990): A polymorphic CACA repeat in the 3 untranslated region of dystrophin. Nucleic Acids Res 18: 1931

Camberlain JS, Gibbs RA, Ranier JE, Nguyen PN, Caskey CT (1988): Deletion screening of the Duchenne muscular dystrophy locus via multiplex DNA amplification. Nucleic Acids Res 16: $11141-11156$

Chamberlain JS, Gibbs RA, Ranier JE, Caskey CT (1990): Multiplex PCR for the diagnosis of Duchenne muscular dystrophy. In: Innis MA, Gelfand DH, Sninsky JJ, White TJ (eds). PCR 
protocols: a guide to methods and applications. Academic Press, New York, London, pp 272-281

Clemens PR, Fenwick RG, Chamberlain JS, Gibbs RA, de Andrade M, Chakraborty R, Caskey CT (1991): Carrier detection and prenatal diagnosis in Duchenne and Becker muscular dystrophy families, using dinucleotide repeat polymorphisms. Am J Hum Genet 49: 951-960

Darras BT, Harper JF, Franke U (1987): Prenatal diagnosis and detection of carriers with DNA probes in Duchenne's muscular dystrophy. N Engl J Med 316: 985-992

Emery AEH (1988): Duchenne muscular dystrophy. 2nd ed. Oxford University Press, Oxford

Feener CA, Boyce FM, Kunkel LM (1991): Rapid detection of CA polymorphisms in cloned DNA; applications to the $5^{r}$ region of the dystrophin gene. Am J Hum Genet 48: 621-627

Fujishita S, Shibuya N, Niikawa N, Nagataki S (1991): Gene-deletion and carrier detections, and prenatal diagnosis of Duchenne muscular dystrophy by analysis of the dystrophin gene amplified by polymerase chain reaction. Jpn J Hum Genet 36: 317-324

Gokgoz N, Kuseyri F, Topaloglu H, Yuksel AM, Kirdar B (1993): Screening of deletions and RFLP analysis in Turkish DMD/BMD families by PCR. Clin Genet 43: 261-266

Koenig M, Beggs AH, Moyer M, Scherpf S, Heindrich K, Bettecken T, Meng G, Muller CR, Lidlof M, Kaariainen $H$, de la Chapelle A, Kiuru A, Savontaus M-L, Gilgenkanz H, Recan D, Chelly J, Kaplan J-C, Covone AE, Archidiacono N, Romeo G, Liechti Gallati S, Schneider V, Braga S, Moser H, Darras BT, Murphy P, Francke U, Chen JD, Morgan G, Denton M, Greenberg CR, Wrogemann K, Blonden LAJ, van Paassen HMB, van Ommen GJB, Kunkel LM (1989): The molecular basis for Duchenne versus Becker muscular dystrophy: correlation of severity with type of deletion. Am J Hum Genet 45: 498-506

Kruyer H, Miranda M, Volpini V, Estivill X (1994): Carrier detection and microsatellite analysis of Duchenne and Becker muscular dystrophy in Spanish. Prenat Diagn 14: 123-130

Kunkel LM, Monaco AP, Middlesworth W, Ochs HD, Latt SA (1985): Specific cloning of DNA fragments absent from the DNA of a male patient with an X chromosome deletion. Proc Natl Acad Sci USA 82: 4778-4782

Kunkel LM, and co-authors (1986): Analysis of deletions in DNA from patients with Becker and Duchenne muscular dystrophy. Nature 322: 73-77

Lindlof M, Karriainen H, Davies KE, de la Chapelle A (1986): Carrier detection and prenatal diagnosis in X-linked muscular dystrophy using restriction fragment length polymorphisms. J Med Genet 23: $560-572$

Lindlof M, Sistonen P, de la Chapelle A (1987): Linked polymorphic DNA markers in the prediction of X-linked muscular dystrophy. Ann Hum Genet 51: 317-328

Lindlof M, Kiuru A, Kaariainen $\mathrm{H}$, Kalimo H, Lang H, Pihko H, Rapola J, Somer H, Somer M, Savotaus M-L, de la Chapelle A (1989): Gene deletion in X-linked muscular dystrophy. Am J Hum Genet 44: 496-503

Oudet C, Heilig R, Mandel JL (1990): An informative polymorphism detectable by polymerase chain reaction at the $3^{\prime}$ end of the dystrophin gene. Hum Genet 84: 283-285

Oudet C, Heilig R, Hanauer A, Mandel JL (1991): Nonradioactive assay for new microsatellite polymorphism at the $5^{\prime}$ end of the dystrophin gene, and estimation of intragenic recombination. Am J Hum Genet 49: 311-319

Roberts RG, Cole CG, Hart KA, Bobrow M, Bentley DR (1989): Rapid carrier and prenatal diagnosis of Duchenne and Becker muscular dystrophy. Nucleic Acids Res 17: 811

Schwartz C, Barjon P (1987): New RFLPs at the DXS164 (pERT87-8) locus in the black population. Nucleic Acids Res 15: 862

Shimmoto M, Tsuji A, Suzuki Y (1988): Restriction fragment length polymorphisms on the short arm of the $X$ chromosome among the Japanese population. Jpn J Hum Genet 33: 333-338

Soong B-W, Tsai T-F, Su C-H, Kao K-P, Hsiao K-J, Su T-S (199I): DNA polymorphisms and deletion analysis of the Duchenne-Becker muscular dystrophy gene in the Chinese. Am J Med Genet 38: $593-600$

Sugino S, Fujishita S, Kamimura N, Matsumoto T, Wapenaar MC, Deng H-X, Shibuya N, Miike T, Niikawa N (1989): Molecular genetic study of Duchenne and Becker muscular dystrophies: Deletion analyses of 45 Japanese patients and segregation analyses in their families with RFLPs based on the data for normal Japanese females. Am J Med Genet 34: 555-561 